\title{
A travessia da autonomia da mulher na pós-modernidade: da superação de vulnerabilidades à afirmação de uma pauta positiva de emancipação
}

\section{The crossing around women's autonomy in the postmodernity: from the superation of vulnerabilities to an affirmation of a positive agenda of emancipation}

\author{
Ana Carolina Brochado Teixeira* \\ Renata de Lima Rodrigues ${ }^{\star *}$
}

\section{Resumo}

\begin{abstract}
O itinerário da mulher no Direito sempre foi marcado pela exclusão e invisibilidade. O presente artigo tem como objetivo analisar a travessia feminina em busca da ocupação do seu lugar como sujeito de direito concreto nos diversos influxos sociais e mudanças históricas. Pretende-se aprofundar em como as transformações influenciaram cronologicamente em aspectos específicos do desenvolvimento das mulheres. Além disso, objetivou-se verificar se, na contemporaneidade, houve evolução em busca da sua emancipação, principalmente no que toca à autonomia corporal, planejamento familiar e aborto.
\end{abstract}

Palavras-chave: Autonomia. Mulher. Vulnerabilidade. Emancipação. Aborto.

\section{Abstract}

\begin{abstract}
The itinerary of women in Law has always been marked by exclusion and invisibility. This article aims to analyze the female crossing around in search of the occupation of its place as a subject of concrete law in the multiple social systems and historic changes. The article intends to increase knowledge of the way that those historic changes influenced chronologically in specific aspects of women development. Further, it aims to verify if, in the contemporaneity, there was evolution in search of its emancipation mainly in what concerns the corporal autonomy, family planning and abortion.
\end{abstract}

Keywords: Autonomy. Woman. Vulnerability. Emancipation. Abortion.

\section{Introdução: Direito como justiça ou como instrumento de exclusão}

O Direito falhou. Tal constatação independe de qualquer concepção de Direito que se queira adotar como referencial teórico. Falhou como Direito Natural, por seu subjetivismo, vagueza de conceitos e falta de necessária imperatividade. Falhou como Direito Positivo, por seu excesso de tecnicismo, formalismo e neutralidade diante da realidade que visa regular, comprometendo o equilíbrio na tensão entre facticidade e validade. Transformou-se em um conjunto de conceitos abstratos a institucionalizar um operacional teórico que muito antes de garantir a função social do próprio Direito, desnaturou-se em instrumento de opressão, dominação social, segregação e de legitimação do poder pelo poder. Falhou ao negar o Direito Natural e estabelecer uma profunda dicotomia entre as normas do Direito Natural, derivadas da razão humana, e as normas do Direito Positivo, derivadas da vontade humana. Diante dessas constatações, nota-se que

Doutora em Direito Civil pela UERJ. Mestre em Direito Privado pela PUC/MG. Especialista em Diritto Civile pela Università degli Studi di Camerino, Itália. Professora de Direito Civil do Centro Universitário UNA. Coordenadora editorial da RBDCivil. Pesquisadora do CEBID. Advogada. Belo Horizonte - MG - Brasil. E-mail: anacarolina@tmg.adv.br.

Doutora e Mestre em Direito Privado pela PUC/MG. Especialista em Direito Civil pelo Instituto de Educação Continuada IEC-PUC/MG. Coordenadora Doutora e Mestre em Direito Privado pela PUC/MG. Especialista em Direito Civil pelo Instituto de Educação Continuada IEC-PUC/MG. Professora de Direito Civil da PUC/MG. Membro do Instituto Brasileiro de Direito de Família - IBDFAM. Advogada. Belo Horizonte - MG - Brasil. E-mail: renatadelima@hotmail.com. 
uma das marcas que a pós-modernidade ${ }^{1}$ impinge ao que se convencionou chamar pós-positivismo e neoconstitucionalismo é a desimportância da discussão que nega a existência de um Direito Natural, ou que estabelece a dicotomia frente ao Direito Positivo.

A aceitação da relação de complementariedade entre Direito e Moral, bem explicitada em Habermas, como meio de viabilizar mecanismos de efetiva concretização do projeto jurídico e político subjacente ao constitucionalismo contemporâneo, para que seja possível de algum modo reaproximar o Direito da noção de Justiça também é outra marca relevante. Trata-se, portanto, de um conjunto de tentativas enfeixadas em torno da necessidade de conferir ao Direito a efetividade e a funcionalidade desejadas em nosso marco civilizatório.

A retomada do debate acerca da relação entre Direito e Justiça busca ressignificar o compromisso do Estado Democrático de Direito brasileiro que, assentado em dois pressupostos essenciais - o pluralismo jurídico e a dignidade da pessoa humana -, tenta equilibrar a historicamente distorcida geografia entre ordem pública e autonomia privada através da função atribuída aos direitos fundamentais, que visam assegurar a autonomia privada dos cidadãos em um contexto no qual experimentamos a descentralização ética, cultural e religiosa de nossa sociedade. Habermas tenta edificar uma teoria que dê real funcionalidade ao Direito na efetivação do projeto das democracias contemporâneas. Segundo o autor, no Estado Democrático de Direito, o devido processo legislativo garante que o processo de formação das normas esteja aberto a toda comunidade. Para tanto, o autor radica o fundamento da autoridade das normas jurídicas - ou seja, o fundamento de legitimidade do próprio Direito - no Princípio do Discurso, de modo que os próprios destinatários das normas sejam também e ao mesmo tempo seus autores. Para chegar a essa colocação, estabelece uma interconexão entre soberania de um povo e direitos humanos, partindo das críticas que opõe às teorias de Kant e Rousseau ao afirmar que ambos se equivocaram ao atribuir a capacidade de autodeterminação exclusivamente ao indivíduo, como Kant fez em "Crítica da Razão Prática", ou ao Estado, como o fez Rousseau em "Contrato Social".

$\mathrm{Na}$ visão de Habermas, Kant se aproximou de um modelo liberal, que enxerga os direitos humanos como garantia de menor intervenção possível do Estado; já Rousseau, por sua vez, se aproximaria do modelo republicano, que trata os direitos humanos como critério de realização ética da sociedade. Habermas se afasta desses dois modelos para preconizar que o nexo interno entre soberania do povo e direitos humanos reside no conteúdo normativo de um "modo de exercício da autonomia política que é assegurado através da formação discursiva da opinião e da vontade, não através da forma de leis gerais". (HABERMAS, 1997, p. 137). Através de um processo dialógico, a sociedade decide quais as normas são válidas, de modo que a linguagem tem papel fundamental para a integração social. Nisso se insere de forma fundamental a ideia de mundo da vida desenvolvida pelo autor em sua obra, a representar um pano de fundo que, apesar de multifacetado, conecta-se através do entendimento, afastando o risco do dissenso e desintegração social. Podemos ainda considerar que o mundo da vida diz respeito a um conjunto de saberes não problematizados, que asseguram um pano de fundo interpretativo e possibilitador de interação social, amortizando o risco de que pretensões de validade sejam sempre recusadas pelos interlocutores, gerando instabilidade. O Direito deve se apresentar como espécie de transformador que impede que essa rede geral de comunicações se rompa, exercendo, portanto, uma função de integração nesse espaço aberto pela racionalização e pulverização do mundo da vida (HABERMAS, 1997, p. 82). Essa função de integração (Direito como medium) prescinde de um equilíbrio entre facticidade e validade, ou seja, um equilíbrio, respectivamente, entre a imposição fática das normas que garantem a ordem (coerção) e a aceitabilidade racional das normas (legitimidade).

\footnotetext{
"Se o termo pós-modernismo tem alguma força ou significação na teoria social, e na teoria social feminista em particular, ela talvez possa ser encontrada no exercício crítico que busca mostrar como a teoria, como a filosofia, está sempre implicada no poder, e que talvez seja isso que sintomaticamente está em funcionamento no esforço para domesticar e recusar um conjunto de críticas fortes sob a rubrica de pós-modernismo. Não é nenhuma novidade que o aparato filosófico, em seus vários refinamentos conceituais, está sempre empenhado em exercer poder, mas de novo é preciso dizer que o pós-moderno não se confunde com o novo; afinal, a busca do 'novo' é a preocupação do alto modernismo; quando mais não seja, o pós moderno lança dúvidas sobre a possibilidade de um 'novo' que não esteja de alguma forma já implicado no 'velho"'. (BUTLER, 2017).
} 
Habermas recorre ao princípio do discurso e da democracia, evidenciando que a autoridade das normas jurídicas reside na deliberação autônoma de sujeitos livres e iguais dentro de um Estado Democrático de Direito, ou seja, naquilo que o autor se refere como sendo um modo de exercício da autonomia política, como mencionado acima. Dessa feita, se as normas jurídicas são feitas a partir de um processo dialógico racional intermediado pela linguagem, é possível equilibrar a tensão entre facticidade e validade, permitindo que o Direito efetivamente promova ou garanta integração social, respondendo a uma das grandes questões da contemporaneidade, que é exatamente esta: como o Direito é capaz de promover ordem e integração social na atualidade, momento em que os projetos de vida são multifacetados e, muitas vezes, antagônicos? Através do discurso e da linguagem são levantadas pretensões de validade, as quais garantem um processo comunicacional, que possibilita um resgate discursivo, já que devem ser justificadas através de argumentos, possibilitando a validade que garante a força do ato da fala. Portanto, a construção das normas legítimas, que irão garantir liberdades individuais, prescinde do uso da autonomia pública dos cidadãos, uma vez que tal legitimidade só pode ser obtida na medida em que as pretensões de validade contidas na norma tenham sido discutidas por todos a partir de um agir comunicativo, voltada para o entendimento e para o consenso.

Para tanto, é fundamental que sejam garantidas a todos, indistintamente, iguais liberdades de atuação e a distribuição equânime de direitos fundamentais, para que todos tenham as mesmas oportunidades e possam participar dos processos de deliberação, pois um sistema jurídico legítimo, no âmbito de um Estado Democrático de Direito, "deve contemplar os direitos fundamentais que os cidadãos são obrigados a se atribuir mutuamente, caso queiram regular sua convivência com os meios legítimos do direito positivo" (HABERMAS, 1997, p. 154).

Habermas irá utilizar essas construções para fundamentar os direitos subjetivos privados e o uso da autonomia privada em um Estado Democrático de Direito. Através da interconexão entre o princípio do discurso e da democracia, Habermas afirma um mecanismo de gênese lógica dos direitos que ocorre através da institucionalização jurídica de condições para um exercício discursivo da autonomia política que acaba por equipar a autonomia privada com a forma jurídica (HABERMAS, 1997, p. 158). Esse tipo de sistema jurídico deve conter direitos que os cidadãos são obrigados a se atribuir reciprocamente, caso pretendam regular sua convivência com os meios do direito positivo, pois determinam o status das pessoas de direitos. Concebendo o Direito como um medium de integração social, no qual as pretensões de validade ou normas de ação levantadas se tornam válidas e todos aqueles por elas atingidos são capazes de dar o seu assentimento na qualidade de participantes de discursos racionais de justificação, a facticidade das normas (coerção) passa a ser constitutiva de interações sociais destituídas de peso moral. O Direito, enquanto medium, pressupõe direitos que definem os status de pessoas como entes portadores de direitos em geral, os quais podem ser talhados pela liberdade de arbítrio de cada um, mas que são moldados externamente por leis coercitivas, isto é, por leis que limitam os espaços de opção a partir de fora para compatibilizar as liberdades subjetivas imputáveis individualmente.

Habermas ainda afirma que a autonomia privada garante uma "liberação das obrigações da liberdade comunicativa" (HABERMAS, 1997, p. 155), ou seja, voltadas para o entendimento ou consenso.Quem toma decisões em nome de suas liberdades subjetivas de ação não precisa se preocupar se os argumentos que são decisivos para cada um poderiam ser aceitos pelos outros. A autonomia privada circunscreve um espaço para o qual o sujeito pode se retirar sem prestar contas publicamente dos argumentos que justificam sua ação.

O pós-positivismo procura constituir institutos e técnicas jurídicas que garantam maior efetividade ao projeto constitucional, de modo que as atuais constituições, já assinaladas pelo fenômeno de transbordamento frente aos ramos infraconstitucionais, apresentem-se como normas formal e materialmente superiores do sistema jurídico, que ultrapassam os horizontes de meras cartas políticas recheadas de fins, diretrizes sociais e intenções institucionalizadas por normas programáticas.

Equilíbrio e inclusão surgem como signos necessários desse discurso contemporâneo, de maneira que o palco dos sujeitos se amplia para permitir a atuação de seres e grupos que tradicionalmente eram invisíveis aos olhos do Direito, ou que tradicionalmente eram visíveis, mas com um status subjetivo subalterno, 
que posicionava certos seres humanos em posições jurídicas detentoras de menos capacidade de direito. Ao afirmarmos a existência de grupos e seres humanos detentores de menor capacidade de direito não violamos as teorias clássicas que afirmam que todo ser humano personificado possui plena capacidade de direito, a exemplo do que preconiza o Código Civil brasileiro. Fato é que o status pessoal atribuído a certos seres humanos, a partir de suas características pessoais, como componente do estado das pessoas naturais, interdita para esses sujeitos o efetivo acesso a posições concretas de titularidade da maioria dos direitos disponíveis na ordem jurídica.

Por mais que a semântica da clássica teoria geral do direito insista em afirmar que é impossível que existam seres personificados que sejam "mais pessoa ou menos pessoa" do que os demais, a realidade é que mulheres, negros, pobres, menores de idade, deficientes físicos e mentais, homossexuais e índios, $v$. g., apresentaram-se - e se apresentam ainda - marginais à cena jurídica da modernidade, que habilmente se construiu como garantidora dos direitos do homem burguês branco, a partir de um evidente horizonte de heteropatriarcalismo.

De nada ou muito pouco adianta afirmar que todos são iguais perante a lei e que todos têm capacidade de direito se o estado pessoal de certos sujeitos não lhes permite concretizar essa capacidade de direito, uma vez que naturalmente não se apresentam em posições jurídicas que the dariam acesso à plenitude de direitos existentes nos ordenamento jurídico. Por essa razão, a eloquente teoria do umbral de acesso ao direito privado, de Ricardo Lorenzetti (1998), apresentada em Fundamentos de Direito Privado, nunca se mostrou tão lúcida e pertinente. Na verdade, além do patrimônio, muitos foram e ainda são os "umbrais de acesso" que impedem a universalização de direitos, garantias e liberdades individuais a todos os seres humanos: o gênero, a cor, a sexualidade, a etnia, a religião.

Diversos são, portanto, os recortes epistemológicos que podem ser estabelecidos para explorar a falibilidade do Direito em suas funções precípuas. Neste texto, importa-nos evidenciar suas falhas em relação à tutela da mulher, de sua negada condição de sujeito pleno de direitos em nossa tradição jurídica, e a consequente luta pela conquista de autonomia e cidadania. A posição de "mulher" em nosso contexto civilizatório há séculos se mostrou como status jurídico subalterno, a lhe garantir menos direitos e liberdades individuais do que a posição de "homem".

\section{A invenção da autonomia feminina}

Quando afirmamos a falência do Direito, na verdade, afirmamos a própria falência da humanidade, que não foi capaz de instrumentalizar suas instituições jurídicas em prol da inclusão e da igualdade. A história do mundo ocidental, em geral fundado em duas tradições jurídicas distintas (direito anglo-saxônico e direito romano-germânico), é rica em exemplos que apontam para a construção de sujeitos - dentre eles, a mulher - que se moldaram a partir da negação, da exclusão e da segregação, cuja tutela jurídica não poderia ser outra se não espelho dessa realidade não paritária, maculada pela cultura do patriarcado, que impôs um padrão normativo de inferiorização às mulheres.

O movimento feminista começa a emergir formalmente em 1791, com a Declaração dos Direitos da Mulher e da Cidadã ${ }^{2}$, de autoria de Marie Gouze, filha de um açougueiro do sul da França, que adotou como pseudônimo o nome de Olympe de Gouges para assinar panfletos e petições na luta por igualdade e contra a escravidão. A Declaração foi uma resposta às conquistas que a modernidade reservou aos homens,

O preâmbulo da Declaração introduz: "Mães, filhas, irmãs, mulheres representantes da nação reivindicam constituir-se em uma Assembleia Nacional. Considerando que a ignorância, o menosprezo e a ofensa aos direitos da mulher são as únicas causas das desgraças públicas e da corrupção no governo, resolvem expor em uma declaração solene, os direitos naturais, inalienáveis e sagrados da mulher. Assim, que esta declaração possa lembrar sempre, a todos os membros do corpo social seus direitos e seus deveres; que, para gozar de confiança, ao ser comparado com o fim de toda e qualquer instituição política, os atos de poder de homens e de mulheres devem ser inteiramente respeitados; e, que, para serem fundamentadas, doravante, em princípios simples e incontestáveis, as reivindicações das cidadãs devem sempre respeitar a constituição, os bons costumes e o bem estar geral. Em consequência, o sexo que é superior em beleza, como em coragem, em meio aos sofrimentos maternais, reconhece e declara, em presença, e sob os auspícios do Ser Supremo, os seguintes direitos da mulher e da cidadã [...]". 
pelas mãos da Revolução Francesa, estampadas na Declaração dos Direitos do Homem e do Cidadão. O documento foi apresentado à Assembléia Nacional da França ainda durante a Revolução Francesa. Ao se opor abertamente contra Robespierre, Marie Gouze acaba guilhotinada em 1793, condenada como revolucionária e como mulher "desnaturada".

O feminismo não é uma corrente única. Os movimentos feministas são muitos, pois se trata de um conjunto de movimentos políticos e sociais e de um conjunto de ideologias e filosofias que têm como objetivo comum o estabelecimento de direitos iguais. Não consiste em um movimento que pregue qualquer tipo de hierarquia entre mulheres e homens ou que afirme a superioridade das primeiras. Ao contrário, luta-se para alcançar uma vivência humana que prescinda do empoderamento feminino para que haja a efetiva libertação de padrões sociais, políticos, jurídicos opressores e patriarcais, construídos a partir do estabelecimento de normas de gênero, que relegaram à mulher papéis subalternos na história da humanidade (ALVES; PITANGUY, 1984).

Trata-se, portanto, de um conjunto teórico que advoga por igualdade material entre homens e mulheres, de modo que o gênero deve importar ao status jurídico do sujeito apenas na medida em que significar alguma vulnerabilidade ou vicissitude que necessite ser compensada ou protegida diante de determinados contextos; efetivando, conforme salientamos, aquilo que deve ser a função social do Direito enquanto instrumento de garantia de iguais liberdades individuais e realizador de justiça em um contexto republicano personalista e plural, no qual o Estado de Direito deve sempre interferir nas liberdades individuais em nome de iguais liberdades individuais.

Desde então, o feminismo vem gradativamente alterando as perspectivas predominantes em diversas áreas da sociedade ocidental, que abrangem desde importantes fatores e tradições culturais até o Direito. As conquistas jurídicas das mulheres ao longo do século passado perpassam liberdades fundamentais tais como o direito de contratar e o direito de ter propriedade privada, passando pela aquisição de direitos políticos, como o direito ao voto, até finalmente alcançar discussões que envolvem o direito da mulher à sua autonomia e à integridade de seu corpo, isto é: o direito ao aborto e os direitos reprodutivos (incluindo o acesso à contracepção e a cuidados pré-natais de qualidade); a proteção de mulheres contra a violência doméstica, o assédio sexual e o estupro; direitos trabalhistas, incluindo a licença-maternidade e salários iguais; e todas as outras formas de discriminação.

\subsection{Primeiro ato: reconhecendo a subjetividade e a cidadania feminina}

Pode-se dizer que, historicamente, os movimentos feministas são divididos por três marcos temporais que estabelecem "três ondas feministas". Assim sendo, a primeira onda do feminismo se refere à atividade feminista desenvolvida durante o Século XIX e início do Século XX em todo o mundo, mas, em particular, em países como França, Reino Unido, Canadá, Países Baixos e Estados Unidos. Isto porque, com o avançar do constitucionalismo clássico e a solidificação da ideia de Estado de Direito em países como Reino Unido, França e EUA, e o consequente fim dos Estados Absolutistas, a conquista de liberdades individuais e direitos políticos pelos homens gera o debate acerca da extensão de sua titularidade às mulheres nesses países.

O feminismo tem sua origem no século XVIII, especificamente no lluminismo, pois esse movimento filosófico gerou controvérsias sobre a igualdade e as diferenças de gênero. As origens políticas do feminismo vieram da Revolução Francesa, cujo marco é o ano de 1789, simbolizado pela queda da Bastilha. Esse evento elevou a igualdade jurídica, as liberdades e os direitos políticos como seus objetivos centrais, mas logo veio a grande contradição que marcou a luta adiantada do feminismo: as liberdades, os direitos e a igualdade legal, que foram as grandes conquistas das revoluções liberais, não afetaram as mulheres. A teoria política de Rousseau projetou a exclusão das mulheres do campo da propriedade e dos direitos. Assim, na Revolução Francesa, a voz das mulheres começou a se expressar coletivamente.

Até o início do século XX, o direito ao voto era um direito exclusivo aos homens, sobretudo aos homens detentores de patrimônio. Entre 1890 e 1994, mulheres da maioria dos Estados adquiriram o direito de votar e se candidatar a um cargo público, por exemplo. Contudo, tal conquista foi alcançada temporalmente e 
espacialmente de forma muito divergente ao redor do mundo. Enquanto mulheres finlandesas comemoravam a vitória já em 1906, ocorreu na África do Sul apenas em 1993 e na Arábia saudita, em 2011.

$\mathrm{Na}$ Grã-Bretanha, o movimento das mulheres conquistou o direito ao voto após a primeira Guerra Mundial. O exemplo das mulheres britânicas espalhou-se pela Europa. Em alguns países, como Suécia e Noruega, o número de eleitoras superou o de eleitores.

Na Inglaterra, Mary Wallstonecraft já tratava dessa demanda em "Reivindicação dos direitos da mulher", publicado em 1792. Mas o movimento pela participação política feminina chamou a atenção da opinião pública em 1903, as suffragettes fundaram o grupo Women's Social and Political Union, que se organizou em quatro tipos principais de militância (técnicas de propaganda, desobediência civil, não violência ativa e violência física) e exerceu influência sobre outros movimentos de mulheres em quase todo o mundo ocidental.

Nas Américas, a Constituição dos Estados Unidos, promulgada em 1787, só definiu o direito de voto para as mulheres através da Emenda Dezenove, em 1919. O movimento sufragista nasceu juntamente com a luta contra a escravidão, em meados do século XIX, e teve grande impulso das sufragistas inglesas. Contudo, as estadunidenses conquistaram o direito ao voto ao mudar o tom de seu discurso. No lugar da pauta feminista, abordaram argumentos acerca dos direitos da raça humana e democracia.

O Equador foi o primeiro país latino-americano a permitir que suas cidadãs votassem, em 1929. Somente há pouco mais de 80 anos as mulheres brasileiras conquistaram o direito ao voto, adotado em nosso país em 1932, através do Decreto n. 21.076, instituído no Código Eleitoral Brasileiro e consolidado na Constituição de 1934. A luta pelo voto já havia começado há mais tempo, de sorte que o Brasil poderia ter sido a primeira nação do mundo a aprovar o sufrágio feminino. Em $1^{\circ}$ de janeiro de 1891 , trinta e um constituintes assinaram uma emenda ao projeto da Constituição conferindo direito de voto à mulher. Tal emenda foi rejeitada. A corrosão nas estruturas sociais e na definição das prerrogativas de gênero comprometeu o exercício do poder sobre as decisões públicas (exercício da autonomia pública), pois o que deveria ser amplo e irrestrito, representativo e proporcional a toda a população, mostrou-se e ainda se mostra marcado por gênero, raça e classe, comprometendo a eficiência de teorias como a teoria habermasiana e, em última instância, desnaturando a legitimidade das normas jurídicas e a própria função social do Direito.

A baixa representatividade das mulheres nas instituições políticas resulta em pouca sensibilidade no mundo político diante da pauta feminista, que é imperiosa para o progresso da sociedade. A luta por participação política é fundamental para a transformação da condição feminina na sociedade.

A luta da mulher por direitos civis e liberdades individuais foi ainda mais lenta no Brasil. Analisando a trajetória da mulher em nossa cultura, nota-se que ela teve educação diferenciada em relação ao homem: enquanto era educada para servir e executar tarefas domésticas, o homem era preparado para assumir a posição de senhor, chefe de família, administrador e detentor de patrimônio, reitor da pessoa dos filhos e da esposa. A mulher solteira vivia sob a dominação do pai ou do irmão mais velho e, ao se casar, passava a se submeter à autoridade de seu marido.

No Brasil-colônia, a Igreja ditava as diretrizes da educação no país, no entanto as mulheres estavam excluídas desse direito. À mulher não era permitido estudar e aprender a ler. Nas escolas, somente Ihes eram ensinadas técnicas manuais e domésticas, perpetuando um estado de ignorância que as mantinham subjugadas a seus homens. Com a mudança da Corte Portuguesa para o Brasil, surgiram algumas escolas não religiosas nas quais as mulheres podiam estudar. Contudo, os estudos se mantinham restritos a trabalhos manuais e domésticos, além do ensino do português de Portugal em nível primário.

A partir da primeira Constituição brasileira, em 1824, surgiram escolas destinadas à educação da mulher, contudo ainda voltadas à instrução de trabalhos manuais, domésticos, cânticos, ensino brasileiro de instrução primária. Mantinha-se a vedação para que mulheres frequentassem escolas masculinas, e somente no início do século XX foi permitido que homens e mulheres estudassem juntos.

Após a independência do Brasil e a promulgação da Constituição do Império, nosso país continuou aplicando a legislação portuguesa. As Ordenações Filipinas eram marcadas pelo conservadorismo medieval do poder patriarcal. O marido era isento de penas, mesmo que infligisse castigos físicos a mulher e aos 
filhos. A mulher não poderia praticar nenhum ato da vida civil sem autorização do marido. Apenas a partir da implantação do regime republicano brasileiro, através do advento do Decreto $n$. 181, de 24 de janeiro de 1890, o marido perdeu o direito de impor castigo corpóreo à mulher e aos filhos.

Apesar do fim da vigência das Ordenações Filipinas no Brasil, no art. 242 do nosso primeiro Código Civil, de 1916, manteve-se os princípios patriarcais de nossa sociedade: o homem permaneceu como chefe da sociedade conjugal; a capacidade jurídica da mulher era relativa a determinados atos, e o artigo 186 estabelecia que, em caso de discordância entre os cônjuges, prevaleceria a vontade paterna. $\mathrm{O}$ artigo 380 do digesto civil atribuía ao homem o exercício do pátrio poder, autorizando seu exercício pela mulher apenas na falta ou impedimento do marido. $O$ artigo 385 conferia ao pai, com exclusividade, a administração dos bens do filho. Mais uma vez, a mãe poderia fazê-lo apenas subsidiariamente, na falta do cônjuge varão (BEVILAQUA, 1980).

\subsection{Segundo ato: igualdade e vulnerabilidades}

A denominada segunda onda do feminismo (ALVES; PITANGUY, 1984) se refere a um período de atividade feminista que se inicia por volta de 1960, nos Estados Unidos, e depois se espalha por todo o mundo ocidental. Nos Estados Unidos, o movimento durou até o início da década de 1980. Enquanto a primeira onda do feminismo se viu centrada na luta pelo sufrágio universal e na derrubada de alguns obstáculos legais à igualdade de gênero a segunda onda procurou ampliar a discussão para outras questões: sexualidade, família, mercado de trabalho, direitos reprodutivos, desigualdades de fato e desigualdades legais.

Em uma época em que as mulheres alcançaram grandes avanços no mercado de trabalho e em cargos militares, além de conquistarem posições e visibilidade nos meios de comunicação e nos esportes, buscava-se também chamar a atenção da sociedade para o imenso número de casos de violência doméstica e problemas de estupro conjugal. Lutava-se pela criação de abrigos para mulheres maltratadas e por mudanças em leis de guarda dos filhos e divórcio.

Como vimos, a evolução da condição jurídica da mulher no Brasil foi lenta e teve alguns marcos importantes: o Estatuto da Mulher Casada; a Consolidação das Leis do Trabalho; a Consolidação das Leis da Previdência Social e as Cartas Magnas de 1934 até a de 1988.

Trinta anos após a conquista do direito ao voto, em 1932, o advento da Lei n. 4.121/62 (Estatuto da Mulher Casada) promove importantes impactos e mudanças no texto do Código Civil de 1916. A principal delas é a retirada da mulher casada do rol de pessoas relativamente incapazes. Finalmente, a mulher casada retoma a liberdade e a autonomia para exercer, por si só, seus próprios direitos e deveres, facilitando seu ingresso no mercado de trabalho, exigido pela industrialização do país e pelas novas relações econômicas. Ainda assim, a mulher se torna mão de obra barata para o capital, recebendo salários menores que os recebidos pelos homens. O artigo 380 do CC/1916 foi alterado para atribuir a ambos os pais o exercício do pátrio poder, prevalecendo a vontade do homem no caso de discordância do casal, ressalvado à mãe o direito de recorrer ao juiz para solução da divergência. O artigo 393, que retirava da mulher o pátrio poder em relação aos filhos do casamento anterior, quando contraísse novas núpcias, também foi alterado, para estabelecer que a mulher manteria os direitos do pátrio poder após novas núpcias.

$\mathrm{Na}$ atualidade, por força da CF/88 e do CC/2002, a mulher casada tem os mesmos direitos e deveres conjugais e parentais que o marido, sem nenhuma distinção. A constitucionalização dos ramos infraconstitucionais do direito e o transbordamento de princípios como a dignidade e igualdade impedem trato jurídico diferenciado de homens e mulheres em nosso ordenamento jurídico.

Ao contrário, as vulnerabilidades físicas da mulher diante do homem e o histórico de desigualdades perpetradas pelo patriarcalismo começam a ser compensadas pelo ordenamento jurídico em busca de efetiva igualdade material. Leis trabalhistas e previdenciárias estabelecem certas prerrogativas às mulheres por ocasião da gravidez e da aposentadoria. O direito penal passa a tutelar a integridade e a vida da mulher como bens jurídicos especiais, diante do contexto de violência doméstica e de misoginia presente em nosso país. Surge, em 2006, a Lei n. 11.340, popularmente batizada de Lei Maria da Penha (BRASIL, 
Lei $11.340,2006)$, que criou mecanismos para coibir a violência domestica e familiar contra a mulher. Em 2015, é promulgada a Lei n. 13.104, que alterou o art. 121 do Código Penal para prever o feminicídio como circunstância qualificadora do crime de homicídio.

\subsection{Terceiro ato: Igualdade e emancipação}

No início da década de 1990, inicia-se a chamada terceira onda do feminismo como resposta às supostas falhas da segunda onda. Procurou-se evitar definições universalistas e essencialistas acerca do feminino como ocorrido anteriormente, que enfatizava excessivamente as experiências das mulheres brancas de classe média alta. Surge a necessidade de difundir a percepção de que as mulheres são de muitas cores, etnias, nacionalidades, religiões e origens culturais. Ao contrário da marcada posição de feministas da segunda onda sobre as mulheres na pornografia, trabalho sexual e prostituição, feministas da terceira onda são bastante ambíguas sobre esses temas, numa tentativa de se estabelecer uma liberdade da mulher de ser o que se quiser ser, independentemente de estereótipos positivos ou negativos compartilhados pelas sociedades.

$\mathrm{Na}$ atualidade, em teoria, já existem instrumentos jurídicos suficientes para proteger as mulheres e compensar certas vulnerabilidades típicas do gênero, tal como a vulnerabilidade física, de modo geral, diante do homem. Contudo, ainda assim, a realidade é rica em exemplos que evidenciam que a posição subalterna da mulher em nossa sociedade, ainda não foi completamente superada. Resquícios culturais do patriarcalismo ainda são encontrados no ambiente familiar, social e profissional.

Mais do que reconhecer a subjetividade feminina e compensar vulnerabilidades em nome de igualdade material efetiva, é preciso permitir que a mulher se construa autonomamente como sujeito e que se emancipe de padronizações culturais que lhe foram cruelmente impostas pelo patriarcado ao longo dos séculos. Para tanto, é inevitável que a discussão sobre a autonomia da mulher seja levada a sério, sobretudo em questões que dizem respeito ao exercício da sua pessoalidade, através do corpo e da sexualidade.

\section{A marca da autonomia no corpo da mulher}

Uma das mais vivas discussões da atualidade se relaciona às alterações no papel da vontade como fundamento da autonomia individual e da possibilidade de autodeterminação no plano jurídico, seja em discussões existenciais, seja patrimoniais. No percurso evolutivo do trato jurídico da autonomia, verificamos que, em um primeiro momento, o que se experimentou foi a requalificação da ideia de autonomia da vontade em autonomia privada. Em um segundo momento, discutiu-se fortemente se a autonomia privada se aplicaria às novas situações jurídicas existenciais, assim como antigas categorias jurídicas, tradicionalmente construídas em torno do patrimônio.

A própria noção de autonomia como poder de autodeterminação na realização de interesses críticos e necessidades humanas transmuda-se para ser tida como categoria relacional, que prescinde da intersubjetividade para a própria afirmação do indivíduo, através de regras verdadeiramente autônomas, diante do mundo, da heteronomia. Por essa razão, inúmeras categorias jurídicas relevantes na estrutura do Direito Privado, tais como a noção de autonomia privada e de dignidade da pessoa humana, devem ser pensadas diante da necessária contextualização que perpassa pela intersubjetividade e pela alteridade para se conformarem adequadamente no marco do Estado Democrático brasileiro.

O princípio da dignidade da pessoa humana surge como garantia de iguais liberdades de atuação para que todos tenham as mesmas oportunidades e a mesma capacidade de se articular e de se tornarem aquilo que querem ser. Há, portanto, um diálogo muito íntimo e primordial entre autonomia, dignidade e direitos fundamentais. Assim, a valorização da autonomia do ser humano como uma das necessidades primordiais do homem se conecta com a própria noção de dignidade.

A discussão sobre a conformação da autonomia privada no Estado Democrático de Direito brasileiro é um dos temas mais recorrentes na doutrina do Direito Privado contemporâneo. Sabe-se que, no desenvolvimento 
de nossa cultura política e jurídica, o balanceamento da medida da intervenção do Estado na vida privada se estabeleceu de formas muito distintas nos três principais marcos políticos de nossa história recente. É possível assentir que, no Estado Liberal, o que se experimentou foi uma profunda valorização dos espaços de autonomia e de valorização da liberdade individual, segundo a ideologia liberal burguesa, como fator determinante no progresso individual. A seu turno, no combate das graves distorções geradas pelo liberalismo jurídico e político, deu-se a máxima intervenção do Estado Social nos espaços de autodeterminação.

Hodiernamente, essa missão é assaz complicada porque, como se vê, restam superadas, de um lado, as tradicionais correntes de justificação do Direito que atribuíam a uma autonomia moral (CHAMON JUNIOR, 2010, p. 18) a fundamentação última dos sistemas jurídicos no paradigma jurídico-liberal, dentro do qual o Direito e os direitos subjetivos por ele assegurados seriam condição de coexistência humana, porque significariam limites às liberdades individuais de seres atomizados, de "mundos individuais" impermeáveis a influências da vida coletiva. Vigorava a premissa de que a personalidade e a liberdade eram conceitos intimamente relacionados com a ideia de propriedade sobre si mesmo, bem como o ideal moral de que o direito viesse a concretizar o equilíbrio entre as vontades de indivíduos, abstratamente e indistintamente, assumidos como iguais.

Por outro lado, resta também superada a tentativa de justificação do Direito em uma autonomia ética (CHAMON JUNIOR, 2010, p. 18) tributável ao paradigma jurídico-social, no qual a premissa vigente era de que o Direito fundava-se em um suposto ethos compartilhado pela sociedade, porque diziam respeito a um pretenso projeto coletivo fruto de uma ordem de valores predominante em um dado espaço e tempo. Ordem de valores que, diga-se, era hipoteticamente assumida como compartilhada por todos, ${ }^{3}$ gerando uma concepção de solidariedade social limitadora da vontade individual, puramente calcada sobre padrões ou standarts comportamentais impostos a cada um de maneira absolutamente acrítica e apriorística.

Atualmente, o desafio que se impõe na reconstrução do Direito privado é encontrar uma justificação do sistema jurídico que não seja fundada em razões morais ou em razões supostamente éticas. Fundamentação que pode até encontrar na normativa da moral dependência e complementariedade, mas não sua razão última de modo que seja possível aos indivíduos, no uso de suas prerrogativas jurídicas, exercer a autonomia privada, ou exercer suas liberdades subjetivas, sem que essas não sejam arbitrárias nem sejam violentamente moldadas por fora.

\subsection{Autonomia corporal da mulher e planejamento familiar}

Segundo o site do Portal Brasil, "o planejamento familiar é um conjunto de ações que auxiliam as pessoas que pretendem ter filhos e também quem prefere adiar o crescimento da família". (PLANEJAMENTO..., 2011, online). Tais ações possibilitam a prevenção da gravidez não planejada e das gestações de alto risco, a promoção de maior intervalo entre os partos, e maior qualidade de vida ao casal que poderá ter somente o número de filhos que planejou. Ainda de acordo com o Portal Brasil, dados da Organização das Nações Unidas (ONU) indicam que os programas de planejamento familiar foram responsáveis pela diminuição de um terço da fecundidade mundial entre os anos de 1972 e 1994. Por sua vez, informações da Organização Mundial de Saúde (OMS) apontam que cerca 120 milhões de mulheres no mundo desejam evitar a gravidez, mas, a despeito disso, nem elas nem seus parceiros usam quaisquer métodos contraceptivos.

Em verdade, conforme defendemos outrora (RODRIGUES, 2015), a definição do direito ao livre planejamento familiar expande as fronteiras estabelecidas pela nossa legislação e exige ser remodelada. Para idealizarmos um conceito de planejamento familiar mais adequado e atual, alguns pressupostos devem ser considerados, sendo eles: i. a dissociação da ética da sexualidade e da ética da reprodução, implicando,

Nesse sentido, seja consentido remeter ao nosso: "Todavia, da mesma forma que no Estado Liberal, onde o exagero da autonomia privada causou a falência do sistema, no Estado Social os excessos da interferência estatal na esfera de liberdade individual fizeram cair por terra postulados que privilegiavam incondicionalmente a vontade coletiva em detrimento da vontade individual. O Estado concebido como a concretização ética de um povo em um determinado momento histórico passou a representar um fim em si mesmo que se chocava com as pretensões individuais de seus membros, pois a vontade coletiva não equivale à soma das vontades individuais dos integrantes da comunidade" (RODRIGUES; RÜGER, 2007, p.19). 
dentre outros fatores, o afastamento do conceito de planejamento familiar da noção de reprodução humana para aproximá-lo da ideia de autoria de projeto parental, por força da pluralidade familiar contemporânea e sua particular principiologia; ii. O trato da (co)titularidade do direito ao livre planejamento familiar nas entidades familiares conjugalizadas e a possibilidade de ser titularizado individualmente por pessoa só enquanto direito fundamental; iii. O avanço da biotecnologia, que permite a ampliação do espaço de decisão dos autores do projeto parental distinguindo ações de planejamento familiar no momento pré-concepção e no momento pós-concepção, o que implica a iv. Ampliação do espaço de decisão dos autores do projeto parental, os quais, por novas técnicas de reprodução assistida, podem assumir tanto o controle da quantidade da prole como o controle da qualidade da prole.

O avanço dos processos sociais, culturais, morais e científicos fez com que a reprodução humana passasse a ser um fator necessário, mas nem sempre imprescindível, para a constituição da condição de parentalidade, uma vez que o ato de ter filhos e constituir prole se distancia hoje, em alguma medida, dos atos biológicos. A condição da parentalidade se liga, apenas em alguma medida, à sexualidade e à família, de modo que, segundo Mário Antônio Sanches (2014, p. 07), em alguns momentos "ela será parte constitutiva da ética da sexualidade e, em outros momentos, ela se abre para aquilo que chamamos de planejamento familiar". Disto inferimos que a ideia de planejamento familiar hoje se emancipa da sexualidade e da reprodução humana biológica. A seu turno, a própria ideia de reprodução humana se desliga em grande medida da sexualidade. Planejamento familiar é condição de possibilidade para a autoria autônoma e responsável do projeto parental.

A reprodução humana, natural ou artificial, é uma das condições de parentalidade, mas não é a única, pois a autoria de um projeto parental pode partir de outros fatos jurídicos, como a adoção. É inegável que existe hoje um distanciamento entre direitos sexuais e direitos reprodutivos, e que todos eles acabam encampados, de alguma maneira, pelo direito ao livre planejamento familiar, mas não constituem exclusivamente o cerne do direito ao livre planejamento familiar.

A rigor, o planejamento familiar se aproxima muito mais dos direitos reprodutivos do que dos direitos sexuais. Contudo, hoje, mesmo em relação aos primeiros, distancia-se e se amplia em possibilidades que ultrapassam o ato de se reproduzir biologicamente, abarcando a condição e/ou necessidade humana de se tornar pai e mãe.

Tradicionalmente, a lei e a doutrina jurídica associam a ideia de planejamento familiar ao uso de técnicas e métodos para conceber ou evitar a concepção, controlando e limitando a existência de prole ou seu tamanho. Muitas das políticas públicas enunciadas anteriormente ocorrem nesse sentido. Contudo, por força dos avanços da biotecnologia, o cenário que se vislumbra na contemporaneidade entrega a cada indivíduo ou entidade familiar uma gama de possibilidades que vai além da simples concepção ou contracepção.

A evolução das técnicas de reprodução assistida permite ao casal uma série de decisões que podem ser tomadas antes da concepção, para evitá-la ou promovê-la, e uma série de deliberações que podem ser assumidas após a efetiva concepção, natural ou in vitro, e que dizem respeito, respectivamente, à possibilidade de realização de um aborto eugênico, como no caso dos anencéfalos, ou da efetiva destinação de embriões obtidos com o uso dessas técnicas para fins reprodutivos ou fins científicos, permitindo ainda aos pais o controle da qualidade dos embriões que serão efetivamente implantados no útero materno para fins de concretização dos ideais reprodutivos protegidos pelo direito ao livre planejamento familiar através do uso de diagnóstico genético pré-implantatório (DGPI).

Sendo assim, afirmamos que o direito ao livre planejamento familiar enquanto direito fundamental se liga ao pleno desenvolvimento da personalidade humana, à saúde e à vida digna, e se revela como situação jurídica complexa, que enfeixa em torno de seu conceito um conjunto de faculdades, deveres, ônus e responsabilidades que se situam em um espaço de liberdade de atuação reconhecido a seu titular. Entretanto, só pode ser plenamente exercido diante de postura ativa, e não interventora, do Estado, no sentido de propiciar a todo indivíduo ou casal subsídios materiais, que englobam desde informações até recursos financeiros, tecnológicos e estruturais. 
Consiste em verdadeira condição de possibilidade para a (não) autoria responsável do projeto parental, abrangendo desde o fato da adoção, o (não) uso esclarecido de métodos contraceptivos adequados e eficientes a cada um, o acesso às mais variadas técnicas de reprodução assistida - que muito além de combater a infertilidade, permitem a autoria do projeto parental diante das diversas necessidades humanas descortinadas por um mundo plural, permeado por diferenças, desigualdades e vulnerabilidades sociais, sexuais e culturais - até acompanhamento do período pré-natal e neonatal. O avanço da ciência impõe o alargamento de seu conceito, pois o planejamento familiar hodiernamente permite ações de controle da quantidade da prole e da qualidade da prole, desde que se trate de escolhas conformadas por suas características permanentes: a parentalidade responsável e a dignidade humana.

Tânia Patriota (2014) comenta que, nos anos 80 , no Brasil, os movimentos de mulheres reivindicavam um programa de saúde da mulher que contemplasse suas necessidades de saúde de forma integral, e não restrito exclusivamente às dimensões de concepção e contracepção. Sendo assim,

o PAISM, Programa de Atenção Integral à Saúde da Mulher, lançado em 1983, propunha-se a atender às necessidades de saúde das mulheres durante seu ciclo vital, dando atenção a todos os aspectos da saúde sexual e reprodutiva. Nesta perspectiva abrangente, pode-se dizer que o movimento feminista havia antecipado em uma década o espírito do Cairo. (PATRIOTA, 2014, p. 35).

O PAISM foi criado no contexto da redemocratização do país e na esteira da Conferência de AlmaAta (1978), que definiu as bases de atenção primária em saúde.

Em 2004, o programa foi transformado na Política Nacional de Atenção Integral à Saúde da Mulher, com o intuito de promover a melhoria das condições de vida e saúde das mulheres por meio da garantia de direitos, ampliação do acesso aos meios e serviços de promoção, prevenção, assistência e recuperação da saúde (TEMPORÃO, 2012, p. 21).

O Portal Brasil afirma que estudos do Ministério da Saúde indicam que em virtude da política de distribuição de meios anticonceptivos houve diminuição no número de gravidezes indesejadas. Esse fator pode ter contribuído com a queda nos índices de abortos inseguros e, consequentemente, na mortalidade materna. A ampliação do acesso aos métodos contraceptivos na rede pública e nas drogarias conveniadas ao programa "Aqui Tem Farmácia Popular" trouxe também como resultado positivo a diminuição de $20 \%$, entre 2003 e 2009, da incidência de gravidez na adolescência (de 10 a 19 anos de idade). Neste sentido, as ações educativas do Programa Saúde na Escola (PSE), criado em 2008, também apoiaram a redução no número de adolescentes grávidas. Entre outras atividades, o programa distribuiu preservativos para cerca de dez mil instituições de ensino, beneficiando 8,4 milhões de alunos de 608 municípios.

Como dito, trata-se de um conjunto de políticas públicas de reprodução humana e de saúde sexual que promovem conscientização e socialização da informação, e que se apresentam coerentemente alinhadas ao conjunto de direitos fundamentais dos cidadãos brasileiros.

\subsection{Autonomia corporal da mulher, planejamento familiar e aborto}

Após tantos avanços na conquista por subjetividade, autonomia e direitos pelas mulheres, um tema ainda divide opiniões, povos e países ao redor do mundo: a questão se o aborto é um direito da mulher, derivado de sua autonomia corporal e de seu projeto existencial de vida digna, e se pode assim ser considerado como ato de liberdade de planejamento familiar.

Existem profundas e irreconciliáveis divergências em torno da temática do aborto e, normalmente, as pessoas se perfilham radicalmente em lados opostos, seja a favor das doutrinas pro life, contra o aborto, seja a favor das doutrinas pro choice, na defesa do aborto. De fato, as discussões sobre planejamento familiar e aborto são muitas vezes inspiradas em orientações distintas do ponto de vista ético, político e jurídico.

Entretanto, acreditamos haver fortes argumentos políticos e jurídicos em nosso contexto e em nosso sistema para adotarmos uma orientação em prol das doutrinas pro choice, sendo possível tratar o aborto eletivo no primeiro trimestre de gestação como um ato que radica sua gênese na autonomia individual, 
a mesma a fundamentar o exercício do direito ao próprio corpo da mulher e o exercício do direito ao planejamento familiar, conforme demonstraremos.

Não ignoramos o fato de que, no estado da arte do Direito brasileiro, o aborto é tipificado como ilícito penal e constitui crime contra a vida, deixando de ser punível apenas nas modalidades de aborto terapêutico, praticado para salvar a vida da gestante, e aborto humanitário ou sentimental, em razão de gravidez fruto de estupro, conforme previsão do Código Penal brasileiro. Acreditamos, contudo, na existência de boas razões políticas e jurídicas para descriminalização do aborto e sua configuração como ato de liberdade corporal e de planejamento familiar.

Também não olvidamos que as perspectivas legislativas não são animadoras. Desde a Constituinte de 1988, a atuação do Congresso Nacional é a que mais impacta negativamente movimentos sociais de defesa dos direitos das mulheres e dos direitos reprodutivos. Segundo a avaliação, de todos os 34 projetos de lei que tramitam hoje versando sobre os direitos reprodutivos, apenas três têm o objetivo de ampliá-los em alguma medida. Dos outros 31 projetos de lei, o Cfemea destaca propostas que se destinam a criminalizar o aborto em casos de estupro e de risco de vida para a mãe, legalmente autorizados hoje, como na hipótese do chamado "Estatuto do nascituro", projeto de Lei n. 478/2007. (CONGRESSO..., 2018, online).

Em 2005, tramitavam na Câmara 33 proposições envolvendo direitos reprodutivos. Desse total, 14 favoreciam a agenda feminista e 19 seguiam no sentido contrário. Ela observa que o quadro mudou, sobretudo após a campanha presidencial de 2010 , quando a questão do aborto se transformou num dos principais pontos de debate eleitoral. Houve um recuo até no meio de parlamentares que, tradicionalmente, apoiavam as feministas. Sendo assim, ao que tudo indica, o Congresso Nacional segue caminho oposto ao caminho trilhado pelo STF. O cenário se opõe aos recentes avanços nas votações do Supremo Tribunal Federal (STF), que autorizam pesquisas com células-tronco, reconhecem a constitucionalidade da Lei Maria da Penha e descriminalizam a antecipação do parto de fetos anencéfalos, entre outros.

Além disso, mais recentemente, o STF decidiu, ao julgar habeas corpus impetrado por pacientes que tiveram sua prisão preventiva decretada pela $4^{\text {a }}$ Câmara Criminal do TJRJ por manterem clínica clandestina de abortos, que o aborto realizado no primeiro trimestre de gestação não seria crime. No HC impetrado perante o STF, os pacientes alegaram que não se vislumbrava os requisitos para decretação de prisão preventiva, nos termos do artigo 312 do Código Processual Penal, sustentando serem réus primários com bons antecedentes, trabalho e residência fixa, além de afirmarem que não houve tentativa de fuga e que a prisão cautelar seria desproporcional, uma vez que, na eventualidade de uma condenação, poderiam cumprir a pena em regime aberto.

Ministro Marco Aurélio Melo, relator do HC no STF, em 08/12/2014, deferiu a medida cautelar pleiteada em benefício de dois dos acusados e, em 27/06/2015, estendeu os efeitos da decisão aos demais corréus. O parecer da Procuradoria-Geral da República opinou pelo não conhecimento do pedido e no mérito pela denegação da ordem, de modo que fosse cassada a liminar deferida aos pacientes. Com o julgamento, o Ministro Marco Aurélio Mello votou pela admissão do habeas corpus e no mérito pelo deferimento da ordem para afastar a custódia provisória, corroborando os termos da liminar que havia deferido anteriormente. Ministro Luís Roberto Barroso pediu vista antecipada dos autos e em seu voto-vista construiu uma argumentação voltada para o deferimento da ordem de ofício e afastou a prisão preventiva dos pacientes e demais corréus considerando a inconstitucionalidade da incidência do tipo penal do aborto no caso de interrupção voluntária da gestação no primeiro trimestre, a partir de uma interpretação conforme a Constituição dos artigos 124 e 126 do Código Penal.

Por outro lado, da lista de projetos acompanhados pelo Centro Feminista de Estudos e Assessoria Cfemea, quatro destinam-se a incluir qualquer tipo de aborto voluntário na lista de crimes hediondos, com penas previstas de até 3 anos para as mães e de 10 a 15 anos para os médicos, e outros dois projetos desejam tipificar o aborto como tortura. Também tramitam cinco propostas parlamentares destinadas a criar formas de apoio às mulheres vítimas de estupro, desde que não optem pelo aborto. Um deles, assinado pelo deputado Odair Cunha (MG), pretende obrigar o governo a garantir uma pensão para as mães até que o filho, fruto do estupro, complete 21 anos. 
O Cfemea também inclui na lista de propostas hostis aos direitos reprodutivos aquelas destinadas a criar uma semana nacional de prevenção do aborto, criminalizar a venda de remédios abortivos e restringir as orientações na rede pública sobre o uso de métodos anticonceptivos.

Sabemos que nenhuma das construções aqui porventura edificadas pode ser efetivamente operacionalizada nos discursos de aplicação normativa sem que antes ocorra uma revisão legislativa descriminalizando o aborto, mas não se pode negar que existe a necessidade de uma política legislativa que leve a sério todas as boas razões e argumentos políticos em prol da legalização do aborto nos discursos de elaboração normativa, bem como boas razões técnico-jurídicas na defesa do aborto como liberdade de planejamento familiar.

Apesar de podermos também pensar o aborto como ato relacionado ao livre planejamento familiar, não há como negar que, tradicionalmente, o debate mundial sobre o tema sempre esteve alinhado, em grande medida, à luta feminista e aos direitos das mulheres. O mesmo se deu no Brasil. É no contexto do movimento feminista organizado da década de 1970 que se coloca com intensidade a luta para reformar o Código Penal em relação ao aborto. A legalização do aborto sempre foi para o feminismo uma questão prioritária de direitos humanos das mulheres. Ao final daquela década, o discurso feminista dos direitos humanos das mulheres assumia, como premissa, o "nosso corpo nos pertence", o que diferenciava o movimento feminista do movimento de mulheres. Para as mulheres feministas, o direito ao aborto, a escolha de ter ou não ter filhos e o livre exercício da sexualidade eram, e ainda são, requisitos básicos e necessários de justiça social para consolidação das democracias (PIMENTEL; VILLELA, 2012, p. 20).

Em razão de fortes embates com a Igreja Católica, a disputa política pelo direito ao aborto tomou força na medida em que esses movimentos passaram a definir como estratégia a defesa do aborto como um direito enfeixado em torno da tutela integral da saúde da mulher. Portanto, a discussão migrou da questão da autonomia para a garantia de acesso a equipamentos sociais. Certo é que discutir o aborto nos força a romper com o paradigma da "maternidade compulsória" (PIMENTEL; VILLELA, 2012, p. 20) e encarar de frente uma realidade na qual inúmeras mulheres abortam na clandestinidade, colocando em risco sua integridade física, psíquica e, fundamentalmente, a própria vida.

Defender a descriminalização do aborto é lutar por um projeto de sociedade equânime nas relações de gênero, tendo a equidade como princípio e diretriz para que as diferenças possam ser convividas e vivenciadas dentro do mesmo. Ao negar a subsunção das mulheres à maternidade, afirmando que elas podem ser mulheres na sua integralidade sem ter filhos e dissociando sexualidade com reprodução, constrói-se a ancoragem necessária para tratar do aborto no âmbito dos direitos humanos e dos direitos reprodutivos e sexuais. Admitindo-se a dignidade humana e os direitos fundamentais da mulher, considerando-se que a vida do feto, em geral, deve ser protegida e reconhecendo que a educação na área da sexualidade e da reprodução humana é, comprovadamente, a única política pública que apresenta resultados satisfatórios na redução da incidência do aborto, conclui-se que qualquer legislação que vise a diminuir a realização de abortamentos deve ser preventiva, e não punitiva (PIMENTEL; VILLELA, 2012, p. 20).

$\mathrm{Na}$ verdade, o debate sobre o aborto não pode ser reduzido em "ser contra" ou "ser a favor" de sua prática. Trata-se de uma visão maniqueísta que reduz as complexidades em torno do tema, transformando-o em uma falácia que se resume à distinção entre aqueles que são pró-vida e aqueles que se denominam pró-eleição. Uma falácia, vale dizer, porque não há lógica em afirmar que os defensores do direito ao aborto são contra a vida. O aborto não é um bem jurídico em si mesmo. Portanto, defender o direito ao aborto não equivale à defesa do aborto ou à sua elevação ao status de bem jurídico tutelável.

Fato é que, nos últimos anos, especialmente a partir da I e II Conferências Nacionais de Políticas para as Mulheres, o trato do aborto assumiu contornos delineados pelas políticas públicas ou, mais assertivamente, contornos delineados pelo âmbito da saúde pública, ao mesmo tempo em que o debate recrudesceu diante do aumento de posições conservadoras que ganharam força política no Congresso Nacional Brasileiro. No Brasil, o que se vê é que, por mais que a legislação seja altamente restritiva e criminalizante, ela não 
é capaz de inibir a prática clandestina do aborto, que ocorre em larga escala ${ }^{4}$ e coloca a vida de milhares de mulheres em risco, sobretudo a vida de mulheres de baixa renda. Nesse cenário, o aborto tem oscilado como a quarta e quinta causa de morte materna ${ }^{5}$ no Brasil (FREIRE, 2012, p. 31).

Contraditoriamente, o Brasil assumiu compromissos em diferentes instrumentos internacionais, através dos quais reconheceu que o aborto inseguro implica violação de direitos humanos de meninas e mulheres, tais como a Declaração de Viena de 1993 e a IV Conferência Mundial sobre a mulher em Pequim, em 1995. O país se comprometeu a tratar a temática do aborto como problema de saúde pública e da necessidade de revisão de sua legislação punitiva sobre o tema.

A avaliação do VI Relatório Nacional Brasileiro fez com que o Comitê de Eliminação da Discriminação contra Mulheres das Nações Unidas recomendasse que o Brasil procedesse à revisão profunda de sua legislação, com objetivo de descriminalizar o aborto, além de promover outras medidas no sentido de incrementar o acesso das mulheres a serviços de saúde sexual e reprodutiva, incluindo a assistência aos casos de complicações advindas de práticas abortivas, uma vez que são elevados os números de mortes maternas no Brasil em virtude do aborto inseguro.

A organização mundial de saúde (OMS) define clinicamente por abortamento a interrupção da gravidez até a $22^{\mathrm{a}}$ semana, com produto da concepção pesando menos que 500 gramas. $O$ aborto é considerado inseguro quando feito em condições sanitárias precárias ou inadequadas e/ou quando realizado por pessoas não capacitadas. A cada ano, cerca de 20 milhões de abortos são praticados no mundo em condições de risco. Quase 95\% desses abortos são realizados em países em desenvolvimento, os mesmos que insistem em manter leis severas e ineptas que proíbem o aborto. Como resultado, até $25 \%$ da mortalidade materna resulta diretamente do aborto inseguro, levando desnecessariamente à morte quase 67 mil mulheres a cada ano. As evidências são contundentes em demonstrar a ineficácia da proibição do aborto como forma de evitar sua prática, contrastando com os efeitos dramáticos da proibição legal sobre a morte de mulheres (DREZETT; PEDROSO, 2012, p. 35-36).

Diante desse panorama, considerando a insegurança e os riscos do aborto clandestino, não é de se espantar que ele seja a quinta maior causa de mortes maternas no Brasil. $O$ aborto tem um custo financeiro tão alto quanto o custo emocional. Calcula-se quanto os governos gastam com complicações de interrupções clandestinas de gravidez. Com base em dados do estudo "Magnitude do abortamento induzido por faixa etária e grandes regiões e do DataSus", realizado pelos pesquisadores Leila Adesse e Mario Giani, com base nos dados do Departamento de Informática do SUS. No ano passado, foram 205.855 internações decorrentes de abortos no país - sendo 51.464 espontâneos e 154.391 induzidos (ilegais e legais).

Levando em consideração que o valor médio da diária de uma internação no SUS é de 413,00 reais e que as hospitalizadas passaram apenas um dia sob cuidados médicos, o governo gastou 63,8 milhões de reais por conta dos abortos induzidos. Em 2013, foram realizadas 190.282 curetagens (método de retirada de placenta ou de endométrio do corpo), a grande maioria de quem quis interromper a gravidez, representando um custo total de 78,2 milhões de reais, já que, pela tabela do SUS, cada intervenção custa, em média, 411,00 reais. No total, chega-se a, no mínimo, 142 milhões de reais. (MULHERES..., 2014, online).

\footnotetext{
No Brasil, os números são os seguintes: "O tabu que cerca o tema leva à imprecisão dos números. Resultados preliminares do estudo 'Magnitude do abortamento induzido por faixa etária e grandes regiões', obtido com exclusividade pelo GLOBO, mostram que, somente no ano passado, foram 205.855 internações decorrentes de abortos no país, sendo que 154.391 por interrupção induzida. Este número, no entanto, é apenas uma ponta do iceberg. As estimativas de abortos do estudo conduzido pelos professores Mario Giani Monteiro, do Instituto de Medicina Social da Uerj, e Leila Adesse, da ONG Ações Afirmativas em Direitos e Saúde, revelam que o número de abortos induzidos é quatro ou cinco vezes maior do que o de internações. Com isso, é possível calcular que o total de abortos induzidos em 2013 variou de 685.334 a 856.668 . No entanto, segundo dados do Ministério da Saúde, foram apenas 1.523 casos de abortos legais (por estupro, ameaças à saúde materna e anencefalia fetal) no período". (MULHERES..., 2014, online).

Segundo Nilcéa Freire (2012, p. 31), "em 2009, foi apresentado um estudo financiado pelo Ministério da Saúde, '20 anos de pesquisa sobre o aborto no Brasil', coordenado por Débora Diniz e Marilena Côrrea, em que se revela o perfil das mulheres que realizam aborto no Brasil, concluindo-se que são predominantemente, mulheres entre 20 e 29 anos de idade, em união estável, com até 8 anos de estudo, trabalhadoras e católicas. Os resultados da pesquisa põem por terra o estereótipo de que somente mulheres 'irresponsáveis' e 'inconsequentes' recorrem ao aborto como solução para o problema da gravidez indesejada e o reposiciona como opção, via de regra difícil, de mulheres e, porque não dizer, de homens, que por diferentes razões vivenciam esta contingência de vida".
} 
Para Ronald Dworkin (2003, p. 143), leis que proíbem o aborto privam ou ferem a liberdade das mulheres, roubando-Ihes oportunidades que podem ser cruciais na vida de cada uma delas. São leis que impõe certo tipo de escravidão e podem significar a destruição de suas próprias vidas. Ele argumenta que o sofrimento causado a essas mulheres por leis antiaborto pode ser traumatizante e insuportável. Neste sentido:

\begin{abstract}
As leis que proíbem o aborto, ou que o tornam mais difícil e caro para as mulheres que desejam fazêlo, privam as mulheres grávidas de uma liberdade ou oportunidade que é crucial para muitas delas. Uma mulher forçada a ter uma criança que não deseja porque não pode fazer um aborto seguro pouco depois de ter engravidado não é dona de seu próprio corpo, pois a lei lhe impõe uma espécie de escravidão. Além do mais, isso é só o começo. Para muitas mulheres, ter filhos indesejados significa a destruição de suas próprias vidas, porque elas próprias não deixaram ainda de ser crianças, porque não mais poderão trabalhar, estudar ou viver de acordo com o que consideram importante, ou porque não têm condições financeiras de manter os filhos. (DWORKIN, 2003, p. 143).
\end{abstract}

Para além da autonomia corporal da mulher, não devemos olvidar que o desejo de não ter filhos e, portanto, de abortar eventualmente, deve ser exercido dentro de balizas conformadoras da autonomia reprodutiva e do planejamento familiar, que derivam precisamente da dignidade humana e da paternidade responsável. Assim, a pergunta que aqui se coloca é se a interrupção voluntária da gravidez pode se encaixar dentro desse âmbito de liberdade.

Para respondermos a essa questão, as seguintes premissas se entrelaçam: $i$. já sabemos que o sistema jurídico brasileiro não trata com absoluteidade o direito à vida humana. A legislação permite a realização do aborto em certas situações. Some-se a isso os precedentes de nossa corte constitucional, que autorizam a pesquisa com células-tronco embrionárias ${ }^{6}$ e também a antecipação terapêutica do feto anencéfalo. ii. A não absoluteidade da vida humana é aferível, independentemente de analisarmos a condição jurídica do nascituro como pessoa, como ente despersonalizado ou como ser humano sem personalidade jurídica, ainda que se trate de um direito conferido a um referencial de imputação, ou quer se trate de um objeto jurídico alvo de um dever, compreendido como espaço de não liberdade de atuação, imputado aos idealizadores do projeto parental; iii. O aborto eletivo, no primeiro trimestre de gestação, não viola a dignidade humana, seja na perspectiva da autonomia, seja na perspectiva da alteridade, que nos impõe um dever de reconhecimento de sua humanidade. Tendo em vista que, no primeiro trimestre de gestação, o feto não tem ainda desenvolvido seu sistema nervoso central, não há violação ao denominado direito fundamental de não sentir dor (SILVA, 2014), revelando-se, a partir disso, a possibilidade de admitirmos o aborto como ato de liberdade de planejamento familiar, para privilegiarmos, em nome de correção normativa, os direitos de liberdade e de autonomia, em prol da vida digna daqueles que não pretendem constituir prole ou levar a cabo a autoria daquele projeto parental.

Assim sendo, na hipótese de aborto eletivo, que pretenda ser realizado mesmo diante da existência de fetos que têm viabilidade de vida extrauterina, estamos a considerar uma situação jurídica concreta na qual se colocam dois referenciais de imputação de direitos e deveres: a gestante ou os pais, (não) idealizadores de um projeto parental, titulares das liberdades enfeixadas no âmbito do direito ao planejamento familiar, e o feto, titular de direitos fundamentais existenciais, como o direito à vida.

Para solução dessa concorrência de dignidades ou de direitos fundamentais não é possível hierarquizar direitos para tratar o direito à vida humana com absoluteidade. Tal posicionamento hermenêutico, assumido aprioristicamente, revelaria uma postura incompatível com a concepção de direito como integridade, defendida anteriormente, e com os ideais de correção normativa que dela derivam. Para analisarmos a questão, é preciso se concentrar na caracterização da amplitude da liberdade de planejamento familiar, para

\footnotetext{
6 "O STF, quando do julgamento da Ação Direta de Inconstitucionalidade n. 3.510/DF, entendeu que o embrião, fruto da fertilização in vitro nas clínicas de reprodução assistida, não recebe a mesma condição de pessoa humana em formação estendida ao embrião fertilizado in utero, cujo desenvolvimento não pode ser obstado por meios externos. A diferença entre este e aquele reside na possibilidade de desenvolvimento do encéfalo, parâmetro do término da vida humana e, por consequência, de seu início. A partir desta premissa - a de que a formação do cérebro determina o início da vida humana juridicamente protegida -, entendeu se, na ADPF n. 54-8/DF, que o feto que padece de anencefalia não pode merecer a mesma proteção estendida aos demais fetos, nos quais esta ocorre sem sobressaltos" (SILVA, 2014, p. 30-31).
} 
concluirmos se o exercício da autonomia reprodutiva para a realização de prática abortiva eletiva estaria a ferir a métrica de iguais liberdades fundamentais a todos distribuídas indistintamente.

Uma vez que defendemos que o direito ao livre planejamento familiar se apresenta como direito fundamental, que se conecta ao pleno desenvolvimento da personalidade humana e que também se perfaz pela (não) constituição de prole, mister se faz averiguar se a permissão para a prática do aborto eletivo como ato de planejamento familiar se impõe no respeito de iguais liberdades de todos os indivíduos envolvidos no caso concreto ou se extrapola os característicos permanentes informados pela dignidade humana e pela paternidade responsável, que informam deveres de respeito à autonomia e à alteridade, prudência e cautela.

Assim, uma das dúvidas que precisa ser elucidada é se a prática do aborto causaria sofrimento fetal ao nascituro ou se haveria algum dado informado pela Medicina e pela Biologia que, de maneira complementar, possa se comunicar ao Direito para determinar um período no qual o aborto possa ser realizado sem causar dor ao ser humano em formação no ventre materno. Tal questão é relevante, uma vez que tanto a natureza humana do feto quanto seu status de referencial de imputação de direitos e deveres comandam a todos nós o direcionamento de um tratamento digno e o respeito aos seus direitos fundamentais.

Marcelo Lucas Sarsur da Silva (2014, p. 17) defende a tese da existência do direito fundamental ao alívio da dor, como consectário do princípio da dignidade humana:

\begin{abstract}
Por direito fundamental ao alívio da dor, compreende-se um direito fundamental implícito, decorrente dos artigos $1^{\circ}$, inciso III (dignidade da pessoa humana), $5^{\circ}$, caput e inciso III (direito à vida e proibição de submissão a tratamento cruel e desumano) e $6^{\circ}$, caput e 196 (direito à saúde) da Constituição da República Federativa do Brasil de 1988 e dos tratados de direitos humanos ratificados pelo Estado brasileiro, entre os quais se destacam a Declaração Universal dos Direitos Humanos e a Convenção Americana sobre Direitos Humanos (Pacto de San José da Costa Rica de 1969). São direitos fundamentais aqueles que compõem o núcleo rígido de uma determinada ordem constitucional, sendo insuscetíveis de emenda voltada à sua supressão ou limitação.
\end{abstract}

Considerando que o princípio da dignidade da pessoa humana é importante característica da liberdade de planejamento familiar, conformando quais práticas consistem em legítimo exercício da autonomia reprodutiva, tal construção acerca do direito fundamental ao alívio da dor, ou seja, do direito fundamental de não ser submetido a tratamentos cruéis e degradantes, mostra-se relevante na análise do aborto eletivo como ato de planejamento familiar. ${ }^{7}$

Ao que se sabe precisar se há dor fetal é tema de difícil análise para as ciências médicas e biológicas, uma vez que os seres humanos em formação no ventre materno não são capazes de expressar dor como nós. A suposição de que o feto venha a sentir dor se relaciona com a formação de certas partes de seu sistema nervoso e à constatada capacidade que eles têm de notar certos estímulos externos. ${ }^{8}$ Marcelo Sarsur da Silva (2014, p. 36-37) levanta alguns dados colhidos em relevantes estudos sobre a dor fetal, realizados nos Estados Unidos, país que autoriza a prática abortiva desde o precedente inaugurado pelo famoso caso Roe v. Wade:

Os estudos médicos sobre a dor fetal, em especial nos Estados Unidos da América, não ocorrem num vácuo normativo. Naquele país, a prática do aborto foi autorizada, em qualquer hipótese, tomandose por base o critério da viabilidade fetal extrauterina. Após alcançar a viabilidade, o feto não mais pode ser objeto de intervenção, mesmo se a gestante assim desejar. Este critério, contudo, não é completamente seguro, nem se pode mensurar apenas pelas semanas de gestação. Ademais, conforme os avanços da medicina neonatal se fazem mais presentes, a viabilidade extrauterina é

Ronald Dworkin (2003, p. 21) destaca: "Sem dúvida, as criaturas capazes de sentir dor têm interesse em evitá-la. Contraria frontalmente os interesses dos animais o fato de submetê-los à dor, quando se os apanham em armadilhas ou se fazem experiências com eles, por exemplo. Da mesma maneira, infligir dor a um feto que já possui um sistema nervoso suficientemente desenvolvido também contraria frontalmente seus interesses. Mas um feto só tem consciência da dor quando sua mãe se encontra em estado avançado de gravidez, uma vez que antes disso seu cérebro ainda não está suficientemente desenvolvido".

8 Entretanto, os fetos, ainda no ventre materno, não possuem capacidade de expressão da dor, sendo impossível mensurar seu desconforto pelos métodos usuais. Logo, a hipótese de que o feto sente dor funda-se em duas dimensões: primeiramente, na formação anatômica das parcelas do sistema nervoso central relacionadas a essa percepção; e em segundo lugar, à capacidade, percebida no feto, de reagir a estímulos externos mesmo dentro do útero (SILVA, 2014, p. 34). 
atingida pelo feto em momentos mais próximos do início da gestação. Em contraponto ao critério fixado pela decisão Roe v. Wade, que parte da admissão da viabilidade extrauterina, alguns Estados daquele país, como Nebraska e Kansas, por exemplo, promulgaram leis que visam a coibir o aborto após a vigésima semana de gestação contada a partir do último ciclo menstrual da mulher, entendendo que existe um interesse estatal prevalecente em coibir o aborto quando recai sobre um feto dotado de sensibilidade à dor (COHEN; SAYEED, 2011, p.1). Os critérios da viabilidade extrauterina e o da formação do sistema nervoso central, embora não coincidentes, aproximam-se de uma mesma realidade: a de que o feto, antes da formação das estruturas cerebrais que lhe permitirão reagir ao mundo que o circunda, não é dotado de interesses ou mesmo de expectativa de direitos. Embora o feto não adquira a personalidade jurídica juntamente com a percepção da dor, há de se entender que ele possui, aos moldes de outros seres dotados de sensibilidade, o interesse em não sofrer agressões que the provoquem sofrimento ou dor física. (SILVA, 2014, p. 36-37, grifos nossos).

Considerando que ainda há incerteza científica em torno da possível capacidade do feto de sentir dor, faz-se necessário adotar uma postura de cautela e prudência para prevenir eventuais violações à sua dignidade humana. Assim sendo, na dúvida sobre a capacidade do feto de sentir dor e, considerando sua vulnerabilidade e o respeito a seus direitos fundamentais, parece-nos salutar que a permissão do aborto eletivo como ato de planejamento familiar deva ter suas possibilidades de realização circunscritas a um determinado lapso temporal.

Assim sendo, restaria vedada a prática abortiva a partir de um determinado período gestacional, qual seja: o primeiro trimestre de gestação, a ser estabelecido com suporte na Medicina e na Biologia, que municiam o Direito com subsídios técnicos acerca do momento de formação do sistema nervoso central, responsável pela percepção da dor. Diante disso, seria possível defender o aborto eletivo como ato de planejamento familiar, uma vez que, realizado dessa forma, representaria ato de controle de prole e de (não) autoria parental, e estaria conformado aos princípios da dignidade humana e da paternidade responsável. Como vimos, o princípio da dignidade humana nos comanda no trato jurídico especial ao nascituro, seja pelo viés da autonomia, seja pelo viés da alteridade. A seu turno, o princípio da paternidade responsável deriva uma série de deveres relacionados, inclusive, com a prudência e cautela, fundamentais diante da imprevisão do exato momento em que surge no feto a aptidão para a percepção da dor.

Além disso, conforme Marcelo Sarsur da Silva (2014) recorda no trecho acima mencionado, é incompreensível que o ordenamento jurídico brasileiro permita a realização do aborto eletivo na modalidade aborto sentimental, sem se preocupar em impor, em respeito à dignidade humana do feto e de seu direito a não sentir dor, um período no qual esse aborto possa ser realizado.

\section{Conclusão}

Na pauta da autonomia da mulher, verificou-se a evolução substancial ocorrida. Os ganhos do passado nos impulsionam a verificar o que ainda precisa ser conquistado para que a igualdade e a emancipação das mulheres façam com que elas possam adonar-se do seu corpo responsavelmente e estar em condição de paridade para compartilhar com o homem decisões, elaboração de leis, feitura e implementação de políticas públicas que possam proporcionar maiores e melhores condições de equilíbrio para que cada um viva a sua vida nos moldes em que escolher.

A discussão sobre o aborto sempre passou pela autonomia feminina, pois abrange o direito da mulher ao próprio corpo, embora não se possa ignorar que é um tema que pressupõe alteridade, por envolver interesses do feto. Como não se sabe ao certo se o feto sente dor, é necessário que o aborto seja praticado apenas em um lapso temporal.

Nesse contexto, a discussão sobre planejamento familiar e aborto é importante, pois ela pode traduzir expressão de autonomia que reflete o projeto de vida individual. As atuais regras sobre a matéria colocam em cheque a travessia da emancipação feminina. A possibilidade do aborto eletivo no primeiro trimestre de gestação pode ser medida de planejamento familiar, pois se refere à construção de um plano parental negativo (quando não se deseja ter filhos), moldado pelas balizas do art. 227 , § $8^{\circ}$ da Constituição Federal, 
quais sejam: dignidade da pessoa humana e paternidade responsável. Assim sendo, faz-se necessário uma revisão legislativa, de modo que o ordenamento jurídico possa corrigir suas falhas e transformar a realidade para potencializar formas de realização da dignidade da pessoa humana, independentemente do gênero, da raça e das suas escolhas existenciais.

\section{Referências}

ABREU, Maria Zina Gonçalves de. Luta das mulheres pelo direito de voto: movimentos sufragistas na Grã-Bretanha e nos Estados Unidos. Arquipélago - Revista da Universidade dos Açores. Ponto Delgada, $2^{\mathrm{a}}$ série, v. VI, p. 443-469, 2002. Disponível em: <https://repositorio.uac.pt/ bitstream/10400.3/380/1/Zina_Abreu_p443-469.pdf>. Acesso em: 22 dez. 2017.

ALMEIDA, Silmara Juny de Abreu Chinelato e. Aborto. Planejamento familiar: Aspectos jurídicos. Conferência sobre População e Desenvolvimento. (Cairo, Setembro de 1994). Revista do Instituto de Pesquisas e Estudos, Bauru, n. 15, ago./nov. 1996.

ALVES, Branca Moreira. Ideologia e feminismo: a luta pelo voto no Brasil. Petrópolis: Vozes, 1980. ALVES, Branca Moreira; PITANGUY, Jacqueline. O que é feminismo. São Paulo: Brasiliense, 1984. ALVES, Leonardo Moreira Barreto. Direito de família mínimo. A possibilidade de aplicação e o campo de incidência da autonomia privada no direito de família. Rio de Janeiro: Lumen luris, 2010.

BEVILAQUA, Clovis. Codigo Civil dos Estados Unidos do Brasil. Edição histórica. Rio de Janeiro: Editora Rio, 1980.

BOBBIO. Norberto. A era dos direitos. Trad. Carlos Nelson Coutinho. Rio de Janeiro: Elsevier, 2004.

BRASIL. Lei 11.340, de 7 de agosto de 2006. Cria mecanismos para coibir a violência doméstica e familiar contra a mulher, nos termos do art. $8^{\circ}$ do art. 226 da Constituição Federal, da Convenção sobre a Eliminação de Todas as Formas de Discriminação contra as Mulheres e da Convenção Interamericana para Prevenir, Punir e Erradicar a Violência contra a Mulher; dispõe sobre a criação dos Juizados de Violência Doméstica e Familiar contra a Mulher; altera o Código de Processo Penal, o Código Penal e a Lei de Execução Penal; e dá outras providências. Disponível em: http://www.planalto.gov.br/ccivil_03/_ ato2004-2006/2006/lei/l11340.htm>. Acesso em: 30 jun. 2018.

BUTLER, Judith. O feminismo e a questão do pós modernismo. Disponível em: <file://C:/Users/Dell/ Downloads/Fundamentos_Contingentes_O_Feminismo_e_a_Questao_do_Pos_Modernismo\%20(4). pdf)>. Acesso em: 22 dez. 2017.

CONGRESSO tem pior atuação em políticas públicas para mulheres desde 88. Observatório UFMA. Disponível em: <http://www.observatorio.ufma.br/index.php/congresso-tem-pior-atuacao-em-politicaspara-mulheres-desde-88/>. Acesso em: 20 fev. 2018.

CHAMON JUNIOR, Lúcio Antônio. Teoria geral do direito moderno. Por uma reconstrução críticodiscursiva na alta modernidade. Belo Horizonte: Lumen Juris, 2006.

CHAMON JUNIOR, Lúcio Antônio. Filosofia do direito na alta modernidade: incursões teóricas em Kelsen, Luhmann e Habermas. Rio de Janeiro: Lumen Juris, 2005.

DECLARAÇÃO DOS DIREITOS DA MULHER E DA CIDADÃ. Disponível em: <http://www. direitoshumanos.usp.br/index.php/Documentos-anteriores-à-criação-da-Sociedade-das-Naçõesaté-1919/declaracao-dos-direitos-da-mulher-e-da-cidada-1791.html>. Acesso em: 27 jun. 2018.

DIMOULIS, Dimitri. Manual de introdução ao estudo do direito. 6. ed. São Paulo: RT, 2014.

DREZET, Jefferson; GALLI, Beatriz; CAVAGNA NETO, Mário. Aborto e objeção de consciencia. Ciência \& Cultura: Revista da Sociedade Brasileira para o progresso da ciência, Campinas, ano 64, n. 2, p. 3234, abr./maio/jun. 2012.

DWORKIN, Ronald. Domínio da vida: aborto, eutanásia e liberdades individuais. São Paulo: Martins Fontes, 2003. 
FRANCO, Camila Ament Giuliani dos Santos; KUSMA, Solena Ziemer. Planejamento familiar com o olhar da saúde pública. In: SANCHES, Mário Antônio. Bioética e planejamento familiar. Perspectivas e escolhas. Petrópolis: Vozes, 2014. p. 49-61.

FREIRE, Nilcéa. Aborto seguro: um direito das mulheres? Ciência \& Cultura: Revista da Sociedade Brasileira para o progresso da ciência, Campinas, ano 64, n. 2, p. 31-32, abr./maio/jun. 2012.

HABERMAS, Jurgën. Facticidad y validez: sobre el derecho y el Estado democrático de derecho en términos de teoría del discurso. Trad. Manuel Jiménez Redondo. Madrid: Trotta, 1998.

MORENO, Nicolás Pájaro. Autonomia privada y constitucionalización del derecho. Bogotá: Universidade Externado de Colômbia, 2006.

MULHERES realizam aborto no Brasil por ano, 850 mil. Pragmatismo político, set. 2014. Disponível em: <https://www.pragmatismopolitico.com.br/2014/09/850-mil-mulheres-realizam-aborto-brasil-por-ano. html>. Acesso em: 22 mar. 2018.

PATRIOTA, Tânia. Relatório da Conferência Internacional sobre população e Desenvolvimento - Plataforma de Cairo, 1994. Disponível em: <http://www.unfpa.org.br/Arquivos/relatorio-cairo.pdf.>. Acesso em: 19 jun. 2014.

PIMENTEL, Sílvia; VILLELA, Wilza. Um pouco da história da luta feminista pela descriminalização do aborto no Brasil. Ciência \& Cultura: Revista da Sociedade Brasileira para o progresso da ciência, Campinas, ano 64, n. 2, p. 20-21, abr./maio/jun. 2012.

PINHEIRO, Rosalice Fidalgo. Planejamento familiar e condição feminina. In: LIU, Alice Bark et al. (Org.). Pela conquista de uma justiça sem fronteiras. Curitiba: OAB Paraná, 2006. v. 3. p. 321-346. (Coleção Comissões. Comissão da Mulher Advogada).

PLANEJAMENTO familiar. Portal Brasil, set. 2011. Disponível em: <http://www.brasil.gov.br/editoria/ saude/2011/09/planejamento-familiar>. Acesso em: 18.mar. 2018.

ROBERTO, Giordano Bruno Soares. Introdução à história do direito privado e da codificação: uma análise do novo Código Civil. Belo Horizonte: Del Rey, 2003.

RODRIGUES, Renata de Lima; TEIXEIRA, Ana Carolina Brochado. Características e consequências do direito ao livre planejamento familiar. In: São Paulo: Atlas, 2010. $\mathrm{O}$ direito das famílias entre a norma e a realidade.

RODRIGUES, Renata de Lima; RÜGER, André. Autonomia como princípio jurídico estrutural. In: FIUZA, Cesar; NAVES, Bruno Torquato de Oliveira; SÁ, Maria de Fátima Freire de. Direito civil: Atualidades II. Belo Horizonte: Del Rey, 2007. p. 03-24.

RODRIGUES, Renata de Lima. Autonomia privada e direito ao livre planejamento familiar: Como as escolhas se inserem no âmbito de autodeterminação dos indivíduos? Belo Horizonte, Pontifícia Universidade Católica de Minas Gerais, 2015. 226f. Tese (Doutorado em Direito). Faculdade Mineira de Direito, Pontifícia Universidade Católica de Minas Gerais, 2015.

RODRIGUES, Renata de Lima. Análise do voto-vista do ministro Luís Roberto Barroso no julgamento do habeas corpus n. 124.306/RJ e seus fundamentos para descriminalização da interrupção voluntária da gestação no primeiro trimestre da gestação. Revista Brasileira de Direito Civil, Rio de Janeiro, v. 10, p. 96-127, out./dez. 2016.

RUZYK, Carlos Eduardo Pianovski. Institutos fundamentais do direito civil e liberdade(s). Repensando a dimensão funcional do contrato, da propriedade e da família. Rio de Janeiro: GZ, 2011.

SÁ, Maria de Fátima Freire de; NAVES, Bruno Torquato de Oliveira. Manual de Biodireito. Belo Horizonte: Del Rey, 2009.

SANCHES, Mário Antônio. Planejamento familiar no contexto da Bioética. In: SANCHES, Mário Antônio. Bioética e planejamento familiar. Perspectivas e escolhas. Petrópolis: Vozes, 2014. p. 7-24.

SHEEN, Fulton J. O problema da liberdade. Rio de Janeiro: Agir, 1945. 
SILVA, Marcelo Sarsur Lucas da. Do direito a não sentir dor: fundamentos bioéticos e jurídicos do alívio da dor como direito fundamental. Belo Horizonte, Universidade Federal de Minas Gerais, 2014. 141f. Tese (Doutorado em Direito). Universidade Federal de Minas Gerais, Faculdade de Direito, 2014.

TEIXEIRA, Ana Carolina Brochado. Saúde, corpo e autonomia privada. Rio de Janeiro: Renovar, 2010. TEMPORÃO, José Gomes. Direitos sexuais e reprodutivos das mulheres no Brasil: conquistas e recentes e desafios prementes. Ciência \& Cultura: Revista da Sociedade Brasileira para o progresso da ciência, São Paulo, ano 64, n. 2, p. 21-22, abr./maio/jun. 2012.

THOMSON, Judith Jarves. A defense of abortion. In: DWORKIN, Ronald (Org.). The filosophy of law. New York: Oxford University Press, 1977. p. 112-128.

TEODORO, Frediano José Momesso. Aborto eugênico. Delito qualificado pelo preconceito ou discriminação. Curitiba: Juruá, 2007.

Recebido em: 08/04/2018

Aprovado em: 03/09/2018 